\title{
Emotional Intelligence among Dental Students
}

\author{
Nurul Afiqah Amani Binti Zaaba ${ }^{1 *}$
}

\section{ABSTRACT}

Emotional Intelligence (EI) is a capability that every person has, which is related with emotions and feelings. Generally, it is capability of individuals to know their own emotions and how to handle them properly. In fact, emotional intelligence is very essential for an individual to achieve success and happiness in life. It need to be handled carefully, especially during the period of adolescent and teenagers, because in this stage a person learns lots of new things and gain experience from it. Thus, they are able to build a good personality and even a better future for themselves.

Keywords: Emotional Intelligence, Dental Students, Feelings.

Life would be very beautiful if we are able to feel it through our heart and emotions. It will be better if we know how to handle the feelings and emotions itself. The way we express it in a proper way, will make our life become meaningful, not even for ourselves but also for people around us. It is not only to involve one soul, but involving a large scale of community and environment. Therefore, this can be approached through the emotional intelligence.

Basically, emotional intelligence is defined as the ability to control one's own emotion [1]. It is the capability of an individual to manage his own emotions and deal with it. As a dental student who will become a future dental professional, it is important to manage their own emotions, as they will deal with lots of patients with difference emotions, attitude and behavior. Thus, it is important for a good dentist to be able to control his own emotions. In fact, during the training period, the performance of the students and their relationship with patients can be seen as it correlates with emotional intelligence.

In addition, Goleman also described emotional intelligence as "the capacity for recognizing our own feeling and those of others, in order to motivate ourselves and managing emotions well in ourselves and in our relationships. It describes abilities distinct from, but complementary to, academic intelligence, the purely cognitive capacities measured by IQ” [2]. Hence, it is

\footnotetext{
${ }^{1}$ BDS I, Saveetha Dental College and Hospital, 162, Poonamalle High Road, Velappanchavadi, Chennai

*Responding Author

(C) 2016 I N Zaaba; licensee IJIP. This is an Open Access Research distributed under the terms of the Creative Commons Attribution License (http://creativecommons.org/licenses/by/2.0), which permits unrestricted use, distribution, and reproduction in any Medium, provided the original work is properly cited.
} 
important for an individual to realize his own feeling, in order to build up positive mind and behavior.

In Salovey and Mayer proposal, they stated that emotional intelligence have five principle features which are as following;

1. Being aware of one's own emotions.

2. Being able to manage one's own emotions.

3. Being sensitive to the emotions of others.

4. Being able to respond to and negotiate with other people emotionally.

5. Being able to use one's own emotions to motivate oneself [3].

On top of that, an individual have a mental ability in which it has the potential to utilize and manage emotions in solving problems [4]. As dental students, it is normal to work under pressure, in order to become a successful dentist. This field is known as one of the hardest field in study. It is important for the students to tackle and cope with stress and pressure environment, under any circumstances. Thus, to handle it in a friendly and positive way, the mental ability and the skill of an individual, will allow them to adjust and adapt successfully to the pressures and the demand environment [4]. The students may tend to experience difficulties when dealing with the stress, however an effective stress management will possibly correspond toward the increase in performance [5].

Therefore, this study was conducted with the aim to investigate the emotional intelligence among dental students.

\section{MATERIAL AND METHOD:}

The questionnaire was drafted carefully by concerning on the important aspect of this research. The significance which are very important for this questionnaire are self-awareness, managing emotions, motivating oneself, empathy and social skill. Through this emotional intelligence among dental students can easily be evaluated.

In addition, in this questionnaire Likert's scale was used for the evaluation and data analysis. The key scored used in this questionnaire are as follow:

\begin{tabular}{|l|l|}
\hline Score & Description \\
\hline $\mathbf{1}$ & Never \\
\hline $\mathbf{2}$ & Rarely \\
\hline $\mathbf{3}$ & Sometimes \\
\hline $\mathbf{4}$ & Usually \\
\hline $\mathbf{5}$ & Always \\
\hline
\end{tabular}

Table 1: Likert's Scale used in Questionnaire. 


\section{Emotional Intelligence among Dental Students}

After the questionnaire was fully prepared, it was distributed among the dental students of Saveetha Dental College, Tamil Nadu, India, as the research was done in his college. About 300 forms were distributed among the students in different years of study, which were in first, second, third, fourth, intern and also among the post graduate dental students.

The respondents were then instructed to fill in the questionnaire with honesty and sincerely. When, they finished answering the questionnaire, it was then collected for further data analysis. Table 2 below show three kind of level of emotional intelligence where the students can be group into. The data from the questionnaire was analyzed and result was tabulated.

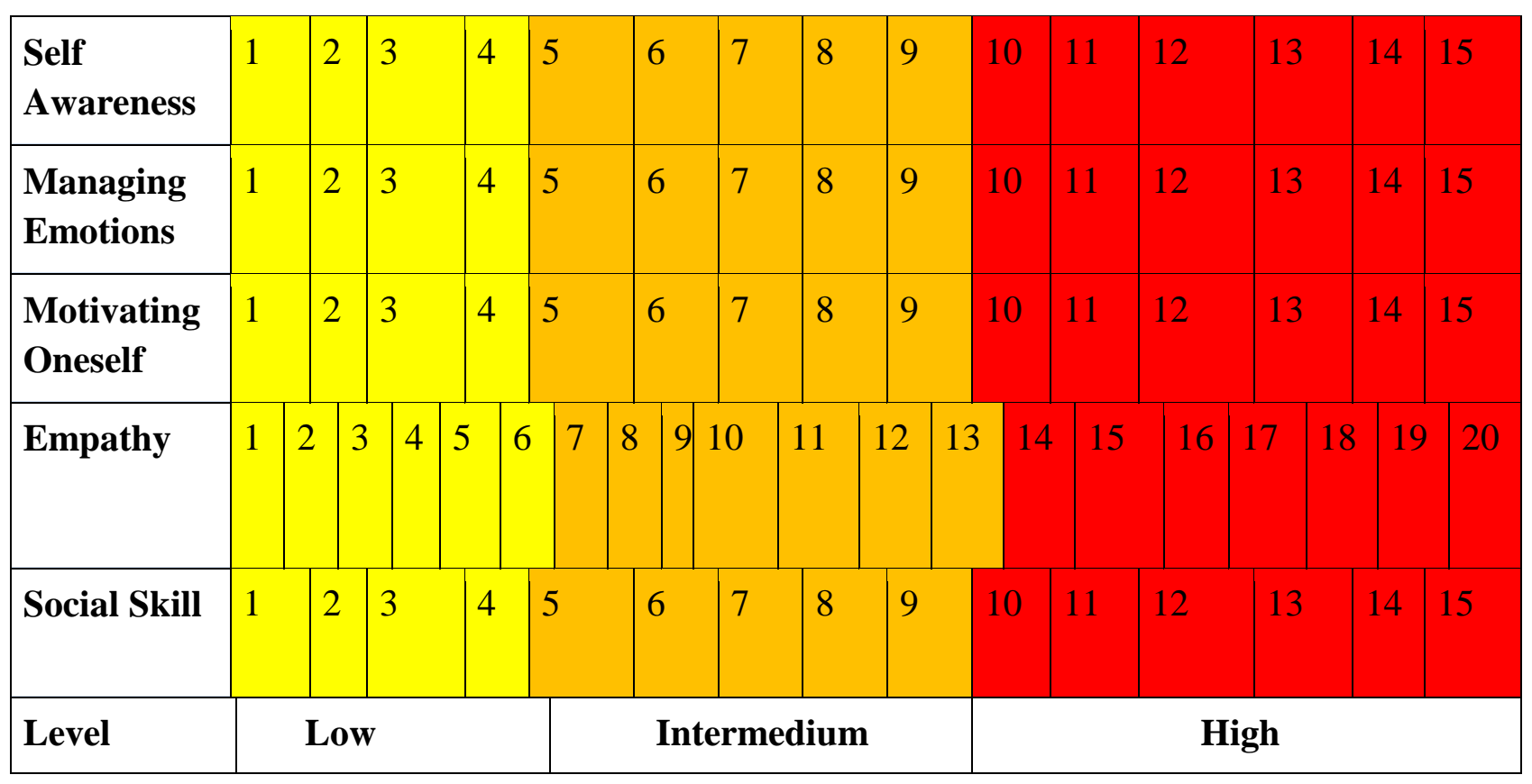

Table 2: Indices for Level of Emotional Intelligence.

\section{RESULT}

In this study, 300 questionnaire were distributed among dental students of Saveetha Dental College in different year of study. This can be seen as in Table 3, where there were 35 students on each first and second years take part in this study. 210 students from third, fourth and intern students, in which in each year there were 70 respondents. There were also participants among the post-graduate students 20 in number. 


\begin{tabular}{|l|l|l|}
\hline Years of Study & Total No. of Respondents & Rate of Response (\%) \\
\hline BDS I & 35 & 100 \\
\hline BDS II & 35 & 100 \\
\hline BDS III & 70 & 100 \\
\hline BDS IV & 70 & 100 \\
\hline BDS V (INTERN) & 70 & 100 \\
\hline MDS (POST-GRADUATE) & 20 & 100 \\
\hline
\end{tabular}

Table 3: Number of Respondents Based on Year of Study.

\begin{tabular}{|l|l|l|l|}
\hline $\begin{array}{l}\text { Level of emotional } \\
\text { intelligence }\end{array}$ & Low & Intermedium & High \\
\hline Self -Awareness & - & 20 & 280 \\
\hline Managing Emotions & - & 63 & 237 \\
\hline Motivating Oneself & - & 31 & 269 \\
\hline Empathy & 1 & 45 & 254 \\
\hline Social Skill & - & 21 & 279 \\
\hline Overall & $0.07 \%$ & $12 \%$ & $87.93 \%$ \\
\hline $\mathbf{N}=\mathbf{3 0 0}$ & & & \\
\hline
\end{tabular}

Table 4: Level of Emotional Intelligence Among Dental Students.

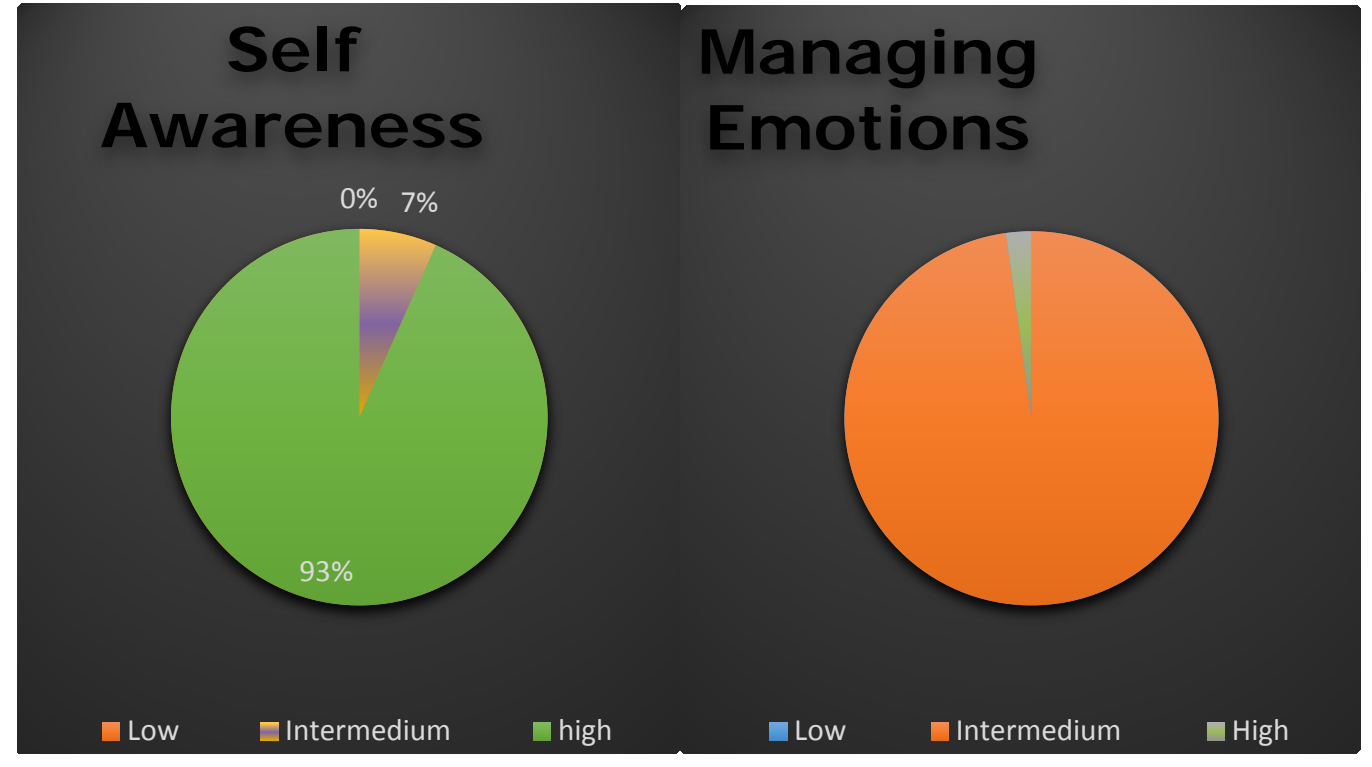

Pie chart 1: Level of EI on Self Awareness

Pie Chart 2: Level of EI on Managing

(c) The International Journal of Indian Psychology, ISSN 2348-5396 (e)| ISSN: 2349-3429 (p) | 23 
Emotions

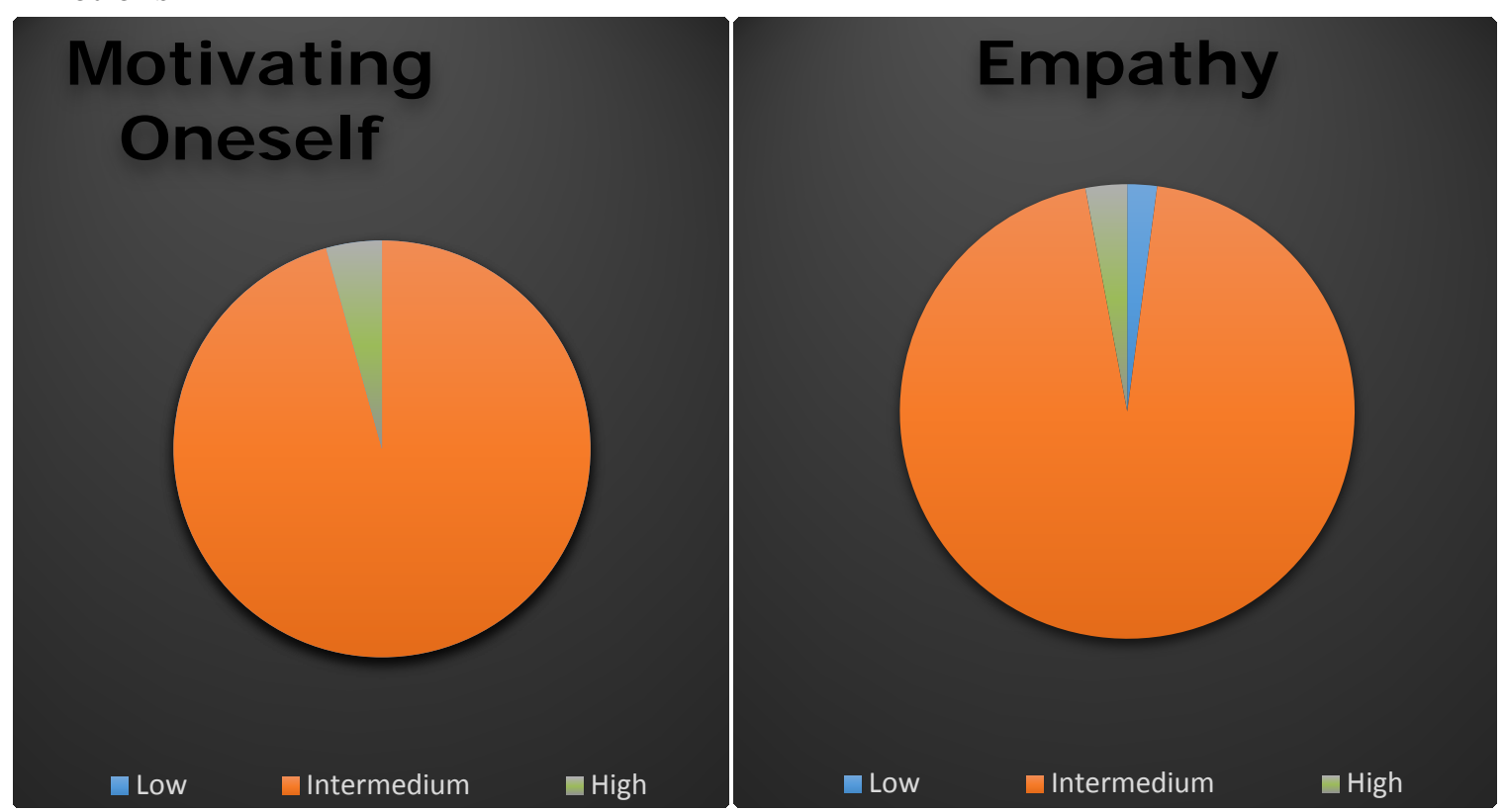

Pie Chart 3: Level of EI on Motivating Oneself $\quad$ Pie Chart 4: Level of EI on Empathy

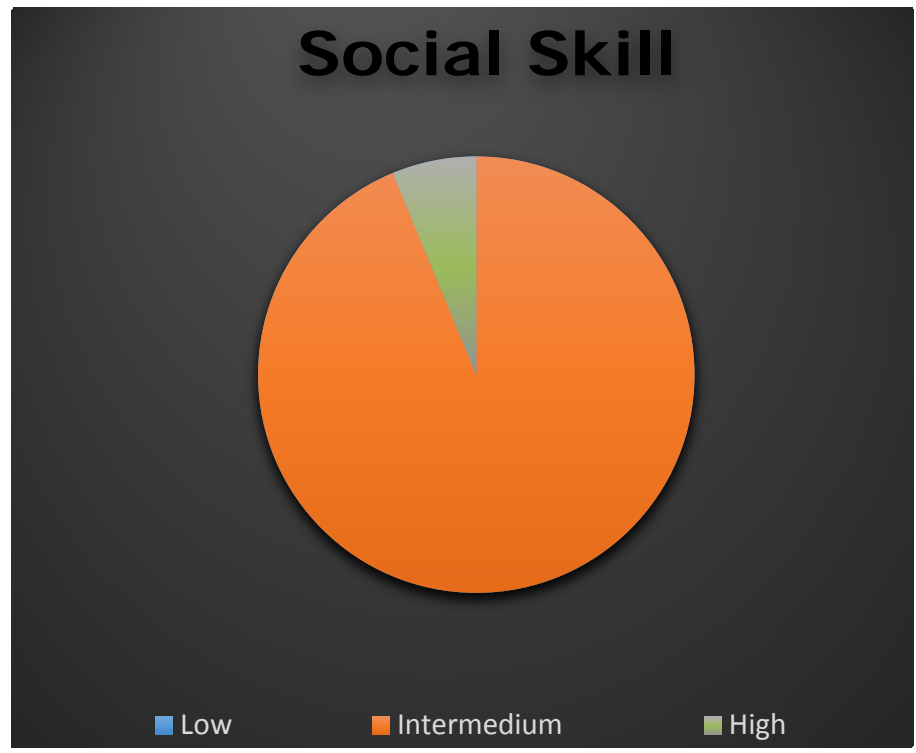

\section{Pie Chart 5: Level of EI on Social Skill}

Table 5, 6, 7, 8, 9 and 10 demonstrates the mean, median, minimum, maximum, range and mode for each year depending on the five important components of emotional intelligence. In each component the value for data was different for each year of study. Averagely, as the students study at higher level, their emotional intelligence also increased. This is because, in a higher education level, the students are exposed with lots of opportunity in dealing with patients with various problems and behavior. This will causes the students to become more maturity and able to handle their emotions along with developing their communication and other skills. Hence, a good bonding in between a dentist and a patient can be developed. 
Table 10 also displayed the mean, median, minimum, maximum, range and mode for overall years depending on the five key important components of emotional intelligence.

\begin{tabular}{|c|c|c|c|c|c|}
\hline $\begin{array}{l}N=35 \\
\text { (BDS I) }\end{array}$ & $\begin{array}{l}\text { Self } \\
\text { Awareness }\end{array}$ & $\begin{array}{l}\text { Managing } \\
\text { Emotions }\end{array}$ & $\begin{array}{l}\text { Motivating } \\
\text { Oneself }\end{array}$ & Empathy & Social Skill \\
\hline Mean & 12.86 & 10.43 & 11.66 & 15.23 & 12.6 \\
\hline Median & 14 & 10 & 12 & 15 & 13 \\
\hline Minimum & 7 & 8 & 8 & 10 & 9 \\
\hline Maximum & 15 & 14 & 15 & 20 & 15 \\
\hline Range & 8 & 6 & 7 & 10 & 6 \\
\hline Mode & 14 & 9 & 12 & 14,17 & 12,13 \\
\hline
\end{tabular}

Table 5: Measure of Central Tendency in Relation to 5 Aspects of Emotional Intelligence of BDS I

\begin{tabular}{|l|l|l|l|l|l|}
\hline $\begin{array}{l}\text { N = 35 } \\
\text { (BDS II) }\end{array}$ & $\begin{array}{l}\text { Self } \\
\text { Awareness } \\
(\mathbf{1 5 )}\end{array}$ & $\begin{array}{l}\text { Managing } \\
\text { Emotions } \\
\mathbf{( 1 5 )}\end{array}$ & $\begin{array}{l}\text { Motivating } \\
\text { Oneself } \\
(\mathbf{1 5})\end{array}$ & $\begin{array}{l}\text { Empathy } \\
\mathbf{( 2 0 )}\end{array}$ & $\begin{array}{l}\text { Social Skill } \\
\mathbf{( 1 5 )}\end{array}$ \\
\hline Mean & 12.09 & 9.8 & 10.66 & 14.91 & 11.63 \\
\hline Median & 13 & 10 & 11 & 15 & 11 \\
\hline Minimum & 6 & 7 & 5 & 7 & 8 \\
\hline Maximum & 15 & 14 & 15 & 20 & 15 \\
\hline Range & 9 & 7 & 9 & 13 & 7 \\
\hline Mode & 1213, & 8,11 & 11 & 15,16 & 11 \\
\hline
\end{tabular}


Table 6: Measure of Central Tendency in Relation to 5 Aspects of Emotional Intelligence of BDS II

\begin{tabular}{|l|l|l|l|l|l|}
\hline $\begin{array}{l}\text { N = 70 } \\
\text { (BDS III) }\end{array}$ & $\begin{array}{l}\text { Self } \\
\text { Awareness } \\
\mathbf{( 1 5 )}\end{array}$ & $\begin{array}{l}\text { Managing } \\
\text { Emotions } \\
(\mathbf{1 5})\end{array}$ & $\begin{array}{l}\text { Motivating } \\
\text { Oneself } \\
\mathbf{( 1 5 )}\end{array}$ & $\begin{array}{l}\text { Empathy } \\
\mathbf{( 2 0})\end{array}$ & $\begin{array}{l}\text { Social Skill } \\
\mathbf{( 1 5 )}\end{array}$ \\
\hline Mean & 12.21 & 11.1 & 11.83 & 15.33 & 11.66 \\
\hline Median & 12 & 11 & 12 & 15 & 12 \\
\hline Minimum & 8 & 7 & 8 & 6 & 8 \\
\hline Maximum & 15 & 15 & 15 & 19 & 15 \\
\hline Range & 7 & 8 & 7 & 13 & 7 \\
\hline Mode & 12 & 11,12 & 13 & 16 & 13 \\
\hline
\end{tabular}

Table 7: Measure of Central Tendency in Relation to 5 Aspects of Emotional Intelligence of BDS III.

\begin{tabular}{|l|l|l|l|l|l|}
\hline $\begin{array}{l}\text { N }=70 \\
\text { (BDS IV) }\end{array}$ & $\begin{array}{l}\text { Self } \\
\text { Awareness } \\
(\mathbf{1 5})\end{array}$ & $\begin{array}{l}\text { Managing } \\
\text { Emotions } \\
\mathbf{( 1 5 )}\end{array}$ & $\begin{array}{l}\text { Motivating } \\
\text { Oneself } \\
\mathbf{( 1 5 )}\end{array}$ & $\begin{array}{l}\text { Empathy } \\
\mathbf{( 2 0 )}\end{array}$ & $\begin{array}{l}\text { Social Skill } \\
\mathbf{( 1 5 )}\end{array}$ \\
\hline Mean & 12.21 & 11.20 & 11.96 & 15.33 & 12.3 \\
\hline Median & 12 & 11 & 12 & 15 & 12 \\
\hline Minimum & 9 & 7 & 9 & 12 & 9 \\
\hline Maximum & 15 & 14 & 15 & 20 & 15 \\
\hline Range & 6 & 7 & 6 & 8 & 6 \\
\hline Mode & 14 & 12 & 12 & 14 & 14 \\
\hline
\end{tabular}


Emotional Intelligence among Dental Students

Table 8: Measure of Central Tendency in Relation to 5 Aspects of Emotional Intelligence of BDS IV

\begin{tabular}{|l|l|l|l|l|l|}
\hline $\begin{array}{l}\text { N = 70 } \\
\text { (BDS V) }\end{array}$ & $\begin{array}{l}\text { Self } \\
\text { Awareness } \\
\mathbf{( 1 5 )}\end{array}$ & $\begin{array}{l}\text { Managing } \\
\text { Emotions } \\
\mathbf{( 1 5 )}\end{array}$ & $\begin{array}{l}\text { Motivating } \\
\text { Oneself } \\
\mathbf{( 1 5 )}\end{array}$ & Empathy & Social Skill \\
\hline Mean & 13.61 & 12.01 & 13.07 & 16.21 & 13.31 \\
\hline Median & 14 & 12 & 13 & 16 & 13 \\
\hline Minimum & 6 & 7 & 6 & 11 & 9 \\
\hline Maximum & 15 & 18 & 15 & 20 & 15 \\
\hline Range & 9 & 11 & 9 & 9 & 6 \\
\hline Mode & 14 & 12 & 13 & 15 & 13 \\
\hline
\end{tabular}

Table 9: Measure of Central Tendency in Relation to 5 Aspects of Emotional Intelligence of BDS V (INTERN).

\begin{tabular}{|l|l|l|l|l|l|}
\hline $\begin{array}{l}\mathbf{N}=\mathbf{2 0} \\
\mathbf{( M D S})\end{array}$ & $\begin{array}{l}\text { Self } \\
\text { Awareness } \\
\mathbf{( 1 5 )}\end{array}$ & $\begin{array}{l}\text { Managing } \\
\text { Emotions } \\
\mathbf{( 1 5 )}\end{array}$ & $\begin{array}{l}\text { Motivating } \\
\text { Oneself } \\
\mathbf{( 1 5 )}\end{array}$ & Empathy & Social Skill \\
\hline Mean & 12.85 & 11.5 & 11.55 & 14.9 & 12.1 \\
\hline Median & 13 & 11 & 12 & 15 & 13 \\
\hline Minimum & 9 & 9 & 9 & 11 & 10 \\
\hline Maximum & 15 & 14 & 13 & 19 & 15 \\
\hline Range & 6 & 5 & 4 & 8 & 5 \\
\hline Mode & 13 & 10,11 & 11,13 & 16 & 13 \\
\hline
\end{tabular}


Table 10: Measure of Central Tendency in Relation to 5 Aspects of Emotional Intelligence of MDS (Post-Graduate).

\begin{tabular}{|l|l|l|l|l|l|}
\hline $\begin{array}{l}\text { N = 300 } \\
\text { (BDS I, II, III, } \\
\text { IV, V \& MDS) }\end{array}$ & $\begin{array}{l}\text { Self } \\
\text { Awareness } \\
\mathbf{( 1 5 )}\end{array}$ & $\begin{array}{l}\text { Managing } \\
\text { Emotions } \\
\mathbf{( 1 5 )}\end{array}$ & $\begin{array}{l}\text { Motivating } \\
\text { Oneself } \\
\mathbf{( 1 5 )}\end{array}$ & Empathy & Social Skill \\
\hline Mean & 12.64 & 11.14 & 11.97 & 15.45 & 12.33 \\
\hline Median & 13 & 11 & 12 & 16 & 12 \\
\hline Minimum & 6 & 7 & 6 & 6 & 8 \\
\hline Maximum & 15 & 18 & 15 & 20 & 15 \\
\hline Range & 9 & 11 & 9 & 14 & 7 \\
\hline Mode & 14 & 12 & 13 & 15 & 13 \\
\hline
\end{tabular}

Table 11: Measure of Central Tendency in Relation to 5 Aspects of Emotional Intelligence of BDS I, II, III, IV, V (Intern) and MDS (Post-Graduate).

\begin{tabular}{|l|l|l|l|l|l|}
\hline $\begin{array}{l}\text { Emotional } \\
\text { Intelligence } \\
\text { Components }\end{array}$ & $\begin{array}{l}\text { Respondents } \\
\text { score 1 (\%) }\end{array}$ & $\begin{array}{l}\text { Respondents } \\
\text { score 2 (\%) }\end{array}$ & $\begin{array}{l}\text { Respondents } \\
\text { score 3 (\%) }\end{array}$ & $\begin{array}{l}\text { Respondents } \\
\text { score 4 (\%) }\end{array}$ & $\begin{array}{l}\text { Respondents } \\
\text { score 5 (\%) }\end{array}$ \\
\hline $\begin{array}{l}\text { Self } \\
\text { Awareness }\end{array}$ & - & 2.89 & 15.56 & 34.33 & 47.22 \\
\hline $\begin{array}{l}\text { Managing } \\
\text { Emotions }\end{array}$ & 2.44 & 10.89 & 22.89 & 37.11 & 26.67 \\
\hline $\begin{array}{l}\text { Motivating } \\
\text { Oneself }\end{array}$ & 0.56 & 8.11 & 17.56 & 31.78 & 42.00 \\
\hline Empathy & 0.89 & 4.78 & 23.78 & 51.78 & 18.78 \\
\hline Social Skill & - & 5.22 & 21.11 & 32.11 & 41.56 \\
\hline $\begin{array}{l}\text { Overall } \\
\text { Percentage }\end{array}$ & 0.78 & 6.38 & 20.18 & 37.42 & 35.25 \\
\hline
\end{tabular}


Table 12: Overall Percentage Score by the Respondents.

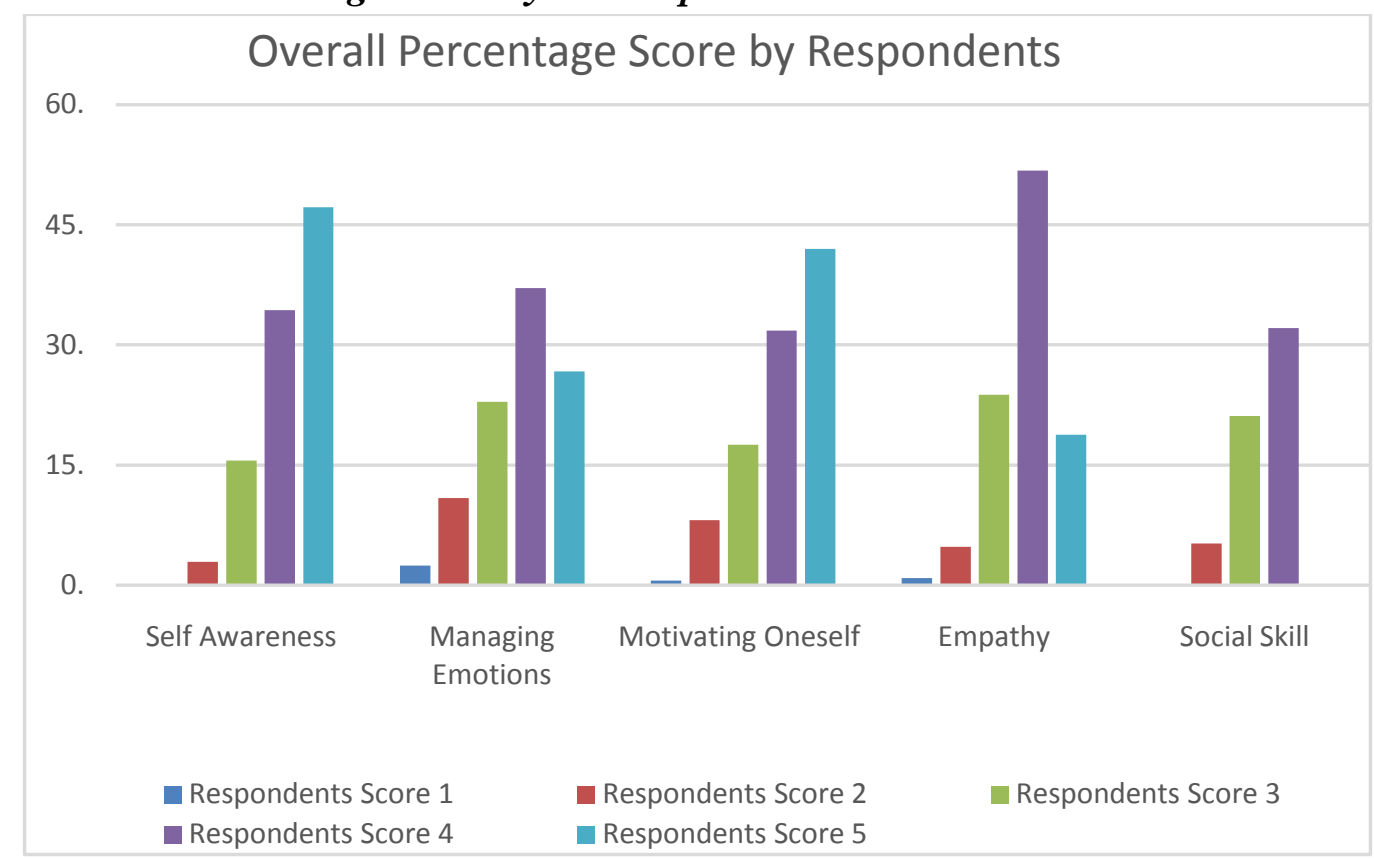

Bar Chart 1: Overall Percentage Score by Respondents.

\section{DISCUSSIONS}

As describe earlier emotional intelligence is the ability of an individual to control their owns emotion. Thus based on this study, the emotional intelligence among the dental students was evaluated. The total of subjects in this study were 300 in number and they are divided based on their year of study. The distributions of the subjects can be seen as in Table 3 .

The emotional intelligence is measured by using the five key components. The components are self-awareness, managing emotions, motivating oneself, empathy and also social skill. Each of the components play a significance role in evaluating the emotional intelligence in an individual. Firstly, the self-awareness, it is mainly about how an individual know very well about himself. In this component, an individual should acknowledge their own emotions and know how his emotions can either affect or not his performance. Besides, it is also important for the individuals to know about his feeling in any time.

The second component is managing emotions. As we know, human being can experience or feel various kind of feelings depending on a particular situation. This feelings can give a positive or negative impact to an individual based on how they able to control it. Thus, it is very important for everyone to know the exact way to handle our mood and emotions. This is because, it also may affect people on our surroundings.

The third component which is motivating oneself is a major thing that everyone must have. It is kind of a good reinforcement in life that give a new shine to people. People who is in high level of this component can able to become a successful person due to positive energy that always 
flow in their body in whatever situation they encounter either it is bad or not. The individual also tend to more important things first and take time as a precious thing for them.

Next is empathy. Empathy is a value that needed by everybody. It is also kind of humanity, where people tend to respect each other, feel empathy, able to see from others perspective and know other people. Through this a good relationship can be fond. Last but not least is social skill. Social skill is a capability where an individual able to interact with the society in a healthy manner. This also help in creating a good relationship and build a good society.

Therefore, as a dental students, all of the five components of the emotional intelligence are very important in developing a good personality. By having a good emotional intelligence, a dentist may capable to dealing with various patients with different problems and emotions. Patients that come visiting the dentists, have different backgrounds and lifestyle. Hence, it is important for dentist to already know a proper way how to manage their emotions and able immerse in any kind of situation. A good social skill and empathy that the dentist show, will build a strong trustworthy of the patients towards the dentist. Hence, there will be less problems or difficulty can happen during treatments. Therefore, this emotional intelligence should be reinforce among the dental students at the beginning of their study, especially during clinical period.

Table 4 illustrates the level of emotional intelligence among the dental students. As we can see, most of the students score high level in every components which is $87.93 \%$. This show that as they learning, their emotional intelligence also develops as well. The clinical exposure also play a major role for them, as they experiencing a new environment and it will be a small step taken by them before they go out and started their career as a dentist.

Next, as we can see in Table 5, 6, 7, 8, 9, and 10, these tables show mean, median, minimum, maximum and mode for each year of study. From these tables, both mean and median values were consistent for each year in every components. This show that the result obtained were comparable in certain aspects. In fact, the overall mean and median for the dental students as described in Table 11 also shown a consistent value. This prove that the students are in a good tract and mostly having a high level of emotional intelligence.

The overall percentage of the students was demonstrated in the Table 12. Roughly more than $50 \%$ students score in key score 3, 4 and 5. About 20.18\% in key score 3, 37.42\% in key score 4 and approximately about $35.25 \%$ score in key score 5 . This prove that the dental students which were the respondents have a very good emotional intelligence.

\section{CONCLUSION}

This research was done to investigate the emotional intelligence among dental students. As this research was done among the dental students, it shows that the students have an excellent emotional intelligence which is $87.93 \%$ and only some of them need to be improved. This 


\section{Emotional Intelligence among Dental Students}

achievement would become a beneficiary not only for the students, but also for the college, society and also country. Thus, the effort toward a good emotional intelligence should always be reinforce and support.

\section{REFERENCES}

[1] Salovey P, Mayer J. Emotional Intelligence. Imagination, Cognition and Personality. 1990; 9; 3: $182-211$.

[2] Goleman D. Working with emotional intelligence. New York: Bantam Books, 1998.

[3] Salovey P, Brackett M, Maye J; Emotional Intelligence: Key Readings on the Mayer and Salovey Model; 2007; $2^{\text {nd }}$ Ed; Dude Publishing USA: 1949-1961.

[4] Kristin Zakariasen Victoroff, D.D.S., Ph.D.; Richard E. Boyatzis, Ph.D. What Is The Relationship Between Emotional Intelligence and Dental Student Clinical Performance?. Journal of Dental Education. Volume 77, Number 4.

[5] Stewart, S. M., Lam, T. H., Betson, C., Wong, C. M. \& Wong, A. M. (1999). A prospective analysis of stress and academic performance in the first two years of medical school. Medical Education 33 (4), 243-250.

How to cite this article: N Zaaba (2016), Emotional Intelligence among Dental Students, International Journal of Indian Psychology, Volume 3, Issue 3, No. 8, DIP: 18.01.136/20160303, ISBN: 978-1-365-12176-0 